\title{
Lexis
}

Journal in English Lexicology

$8 \mid 2014$

Metaphor Studies in the English Language

\section{Conceptions of Copyright in a Digital Context}

A Comparison between French and American File-sharers

\section{Stefan Larsson}

\section{(2) OpenEdition \\ Journals}

Electronic version

URL: http://journals.openedition.org/lexis/244

DOI: $10.4000 /$ lexis. 244

ISSN: 1951-6215

Publisher

Université Jean Moulin - Lyon 3

\section{Electronic reference}

Stefan Larsson, « Conceptions of Copyright in a Digital Context », Lexis [Online], 8| 2014, Online since 09 January 2014, connection on 01 May 2019. URL : http://journals.openedition.org/lexis/244 ; DOI : $10.4000 /$ lexis. 244

This text was automatically generated on 1 May 2019.

\section{(2) $\odot \Theta \Theta$}

Lexis is licensed under a Creative Commons Attribution-NonCommercial-NoDerivatives 4.0 International License. 


\title{
Conceptions of Copyright in a Digital Context
}

\author{
A Comparison between French and American File-sharers
}

\author{
Stefan Larsson
}

\section{Introduction - metaphors we file-share by}

1 When Lakoff and Johnson [1980] wrote their ground-breaking Metaphors We Live By, they pointed out the absolute importance of metaphors for conceptual processes and abstract thinking. Theoretically and empirically, they countered a widespread notion of the metaphor as simply an ornament of words bearing no deeper meaning for our thinking or our minds and showed that the metaphor has a fundamental role in how our thinking and meaning-making is conducted, stating that abstract concepts are largely metaphorical ([1980]; cf. Lakoff \& Johnson [1999]). For example, they claimed that "our ordinary conceptual system, in terms of which we both think and act, is fundamentally metaphorical in nature" (Lakoff \& Johnson [1980/2003: 3]). This means that unlocking the metaphors constantly present in our language and mind - which are here argued to also be relevant to law and norms - may reveal to us how they are connected, what values and associations they bring, and on what conceptions they are founded. Scholars such as Johnson [2002; 2007], Winter [2001; 2007; 2008; 2011], and Larsson [2011a; 2012a; 2012b; 2013a; 2013b] have focused on the legal implications of the conceptual metaphor perspective, the latter doing so particularly within the context of the Internet and digitisation. Larsson [2011] argues that digitisation in society requires a remarkable need for metaphors and embodiment in order to speak and think of the partly new phenomena that it brings with it (cf. Larsson [2013b]).

2 Although Lakoff and Johnson did not predict the massive transformations that digitisation brings, in what Castells described as a "rise of the Network society" (Castells [1996]), the conceptual developments and challenges that digitisation presents are huge (Larsson [2012b]). Larsson [2012b] studies the conceptual development of the "copy" as regulated by copyright. The metamorphosis is immense, yet somewhat hidden: 
Given that the conditions under which digital media are distributed have changed so fundamentally - from having been stored on various types of well-defined and delimited plastic objects to being disseminated as digital files in networks - the concept of "copy" has expanded to embrace a number of new phenomena consisting of a multitude of file formats for storing and distributing information in digital form. These phenomena possess attributes that resemble those of the original ones (i.e. reproducibility) but also attributes that do not (non-materiality). The fact that copies in a copyright sense once only meant physical entities and now mean both physical as well as digital entities describes a conceptual development of "the copy" [Larsson 2012b: 3].

Thereby, Larsson is able to demonstrate that the law is currently undergoing some sort of conceptual change without it being explicitly revised. Herein lies, arguably, a key to understanding why copyright has such weak representation in social norms in a digital society [Larsson 2011a], as discussed and studied by many others (Feldman and Nadler [2006]; Karaganis et al. [2012]; Lessig [2008]; Svensson \& Larsson [2012]). When familiar words in a tangible context are also used to include actions in a digital environment, not only does this challenge our understanding of computer-mediated behaviour but also the laws that seek to regulate us - laws that often have been conceived in pre-digital circumstances.

4 In May 2012, The Swedish Cybernorms research group conducted a survey of over 96,000 respondents on file-sharing in collaboration with the infamous BitTorrent tracker The Pirate Bay. It is the responses from the almost 20,000 French and US respondents that are analysed in this study. One section of the survey included an open-ended question that concerned future perspectives on the Internet and on file-sharing. This means that this data is a rich source for studies on how this near global file-sharing community conceptualises these issues and how they understand and describe both the current as well as the future situation via words and metaphors such as 'theft', 'sharing', 'market', 'surveillance', 'law', etc. (cf. Andersson Schwarz \& Larsson [2013]; Larsson et al. [2012]).

\subsection{Purpose and research questions}

5 Given the challenges that Intellectual Property (IP) regulation faces in a digital context, the purpose of this article is to better understand how file-sharers conceptualise both copyright and the unauthorised file-sharing often called 'online piracy.' In order to achieve this aim, the article can be broken down into a number of questions that simultaneously set some of the methodological and theoretical conditions:

1. What metaphors do online file-sharers use to conceptualise copyright in a digital society?

2. How do they understand property and intellectual property in this context?

3. How do they view the file-sharing community and how does this 'online piracy' connect or not connect to law, social norms, copyright enforcement, and computational traceability?

4. Given the historical variations in the inherent emphasis on ownership and attribution in copyright law in an American vis-à-vis a French continental context, are there, for example, noticeable differences between the American and the French respondents?

6 The first question concerns the explicit metaphors employed in this discourse. In this study, most of the material comes from the open-ended question in the large online survey. The second question corresponds to an on-going debate concerning the extent to which IP regulation attempts to colonise or tap into how tangible property is conceptualised and regulated, and focuses on the P in IP in order to achieve more benefits 
for the rights-holders (cf. Herman [2008]). The third question is an attempt to study how the community regards itself, which is linked, for example, to conceptions of "sharing is caring", technological determinism, and other modes of justification (cf. Andersson Schwarz \& Larsson [2013]). Finally, the fourth question, which may come across as rather ambitious, addresses the fact that copyright and IP regulation have developed in cultures and traditions that differ somewhat, particularly in what is often regarded as the difference between the more economically bound and trade-related (sometimes described as utilitarian) tradition and the author-focused droit d'auteur tradition.

\section{Metaphors and conceptions}

7 In approaching an analysis of the metaphors in copyright, the research on metaphors in cognitive linguistics constitutes our guideline. Lakoff's and Johnson's Metaphors We Live By [1980] represent an early catalyst for this school of cognitive metaphor studies. Their work has been followed by many others and has been used in other disciplines, including law (Berger [2004; 2007; 2009]; Blavin \& Cohen [2002]; Cass \& Lauer [2004]; Herman [2008]; Hunter [2003]; Johnson [1987, 2007]; Joo [2001]; Lakoff [1987]; Lakoff \& Johnson [1999]; Lakoff \& Turner [1989]; Ritchie [2007]; Patry [2009]; Tsai [2004]; Winter [2001; 2007]). Of relevance here is Steven Winter's A Clearing in the Forest [2001], further commented upon by Johnson [2007], in which Winter describes extensively the impact of viewing law from a conceptual metaphor perspective which also encompasses embodiment and categorization (cf. Larsson [2013a]). The key function of metaphors is the application of the image of a source domain to a target domain. This is particularly relevant for abstract phenomena which, according to Lakoff and Johnson [1999], are mainly metaphorical.

8 Further, this being the main point in Lakoff's and Johnson's work, we inevitably depend on metaphors for conceptual processes. This means that our mind and thinking rely on metaphorical operations to work the way they do. This also means that metaphors often come in clusters (Larsson [2011b: 60-61, 72-73]; Loughlan [2006]) or, rather, that Lakoff and Johnson focus on the conceptual metaphors that may have a number of lingual expressions which communicate the conceptual metaphor they relate to. They argue through examples of metaphors such as LOVE IS A JOURNEY that our ways of understanding love are very much related to the attributes of a journey. Therefore, it is meaningful to say that "our relationship has hit a dead-end street", "we're going in different directions", or "our relationship is at a crossroads", etc. [Lakoff 1986]; [Lakoff \& Johnson 1999: 123].

\subsection{Copyright as property}

One particularly durable strand of critique concerning copyright regulation addresses the romanticised notions of the individualist creator, often named the "solitary genius" (Arewa [2006]; Patry [2009]; Rose [1993]). This individualistic view of authorship and the emphasis on the role of property rights for literary production is at the core of this legacy and has been key in explaining the purpose of, and justification for, the existence of a functioning copyright law (Fredriksson [2009]; Jakobsson [2012]; Rose [1993]; Woodmansee [1994]). Herman [2008] has analysed how copyright is increasingly described in rhetorical terms that indicate tangible property, i.e., conceptualised as property, which leads to stronger rights for the rights-holders. 

holders, predominantly from the US, speak of "theft", "trespassing", and "piracy" when describing copyright infringing file-sharing (Herman [2008]; Larsson [2012a; 2012b]; Larsson \& Hydén [2010]; Loughlan [2006]). This has been described as a colonizing trend in copyright [Larsson 2011b] and is particularly relevant here in relation to the opposing conceptualization of shared media content that the file-sharing community likely entertains. This development, which has mainly been linked to the American context, can already be noted in the way MPAA president Jack Valenti spoke of "creative property" before the US Congress in 1982 [Lessig 2004: 116f.]. This is an example of how the procopyright industry constructs property-based claims on the intangible goods being copied in the digital sphere because it benefits their industry [Larsson 2012b]. According to Jakobsson, for example, the increased use of the concept of intellectual property can be understood through the development of increasingly neoliberal influenced media politics [2012: 72], and Jakobsson argues that this is particularly true of the US where the protection of private property has strong cultural roots.

\subsection{Copyright infringement and social norms}

11 Within sociology and socio-legal research, emphasizing the correlation between perception and action is not a new idea. For example, sociologist of law Banakar brings up Petrażycki's analysis of intuitive and official law and concludes that there is undoubtedly a link between perception (attitude, opinions, and beliefs) and action (behaviour and conduct) [Banakar 2012: 15]. This has also, from a contemporary perspective, shaped theories on norms (social, legal, etc.) and their relation to cognition (cf. Hydén \& Svensson [2008]; Svensson [2008]). This concept of norms has been used to measure the strength (or weakness, in fact) of social norms that correspond to copyright in a digital context (Svensson \& Larsson [2012]; Svensson et al. [2014]). Within the scope of this article, this is mainly of interest, as far as the conceptual aspect is concerned, to the extent that norms relate to conceptualisation such as conceptual metaphors and categorisation, as Larsson [2013a] argues. The link would then be that the way in which the digital environment mediates the sharing of movies, music, games, etc., is relevant in that the law is not perceived as normatively correct. The law is also mentioned in the Larsson article cited above (2012b]: "legal conception of copies and the importance of control over their distribution and reproduction may be less meaningful to those, often younger [users], that are used to the sharing of copies in a digital environment" [2012b: 17]. Larsson suggests this as part of the explanation for why the social norms correlating to copyright are weak in these groups [2012b: 17].

\subsection{France and The US: Legal, lingual and conceptual differences}

12 In Cosmopolitan Copyright [2011], copyright analyst and professor of library and information science Eva Hemmungs Wirtén studies the more than a century old historical background to contemporary copyright. She addresses the lingual differences in the time of the drafting of the 1886 Berne Convention for the Protection of Literary and Artistic Works, claiming that the Convention is a "negotiation between legal systems, between copyright and droit d'auteur, between civil law and common-law traditions" [2011: 11]. With this, one might contend, she focuses on conceptual differences that accompany lingual cultures, 
and she further states that "one could argue that there have been two Empires in the history of international intellectual property relations: the French and the American. Both 'imperialisms of the universal,' have cemented their power with the aid of an interface that is not so much territorial as it is symbolic: language" [Hemmungs Wirtén, 2011: 74]. She addresses Silke von Lewinski's [2008] International Copyright Law and Policy, in which von Lewinski concludes that "it may be worthwhile studying whether the prevalence of the English language has had an impact on the perception of this field of law, or given rise to a possibly enhanced influence of 'copyright thinking"' [2008: vii]. This can be taken as support for surveying the conceptualisation of IP in French speaking parts of the world in comparison with a US perspective.

For example, Jakobsson [2012] suggests that the different, geographically bound origins of liberal and romantic notions of copyright have had implications for copyright development in various countries [2012: 66]. One can, therefore, distinguish between UK/ US copyright in the utilitarian tradition and continental European droit d'auteur tradition [Samuelson 1999]. The utilitarian tradition attaches great importance to the benefits of copyright for the whole of society. Countries that instead follow the droit d'auteur tradition tend to emphasise the author's individuality and what is perceived as the special bond between the author and his works [Jakobsson 2012: 66]. For example, copyright in this tradition, as in France, often includes the less easily traded or sold "moral rights" next to "economic rights."

In order to relate the possible lingual and conceptual differences between cultures and languages, I would like to refer to the Swedish social psychologist and translator Johan Asplund who was inspired by Foucault and, to some extent, Lakoff. Asplund uses the concept of "thought figures" to explain the difference between translatability and understanding. Asplund explains that when discourses have developed in different languages but are based on similar thought figures, or thought figures that both discourses utilise, the opportunities to understand each other are good, even if the exact translations of the actual concepts and terms are not possible. In contrast, if they develop their discourses in relation to thought figures that the other party does not utilise, they cannot understand each other. Asplund concludes that this could even be the case where two speakers of the same language are concerned [Asplund 1991: 16]. This may be compared to historical linguist Richard Trim's comparative theory of languages which is more clearly influenced by Lakoff and Johnson and resembles Asplund's presentation. Trim claims that there are probably three main combinations of two basic forms: 1) two languages that share the same linguistic form and the same conceptual metaphor (this is then both translatable and understandable, to use Asplund's terms); 2) two languages that share the same conceptual metaphor but not the same linguistic form (it is not translatable but understandable); and 3) two languages that share neither, i.e., one conceptual metaphor may exist in one language with no equivalent in another, or they may have two different conceptual metaphors that convey the same figurative meaning (neither translatable nor understandable) [Trim 2007: 28-29]. In short, Asplund and Trim seem to aim for a similar purpose, but from different scholarly backgrounds. It is argued, therefore, that Asplund's conception of thought figures is, to a considerable degree, translatable to the theory of conception postulated here and is strongly indebted to the conceptual metaphor theories of Lakoff and Johnson. It is not surprising to see that Asplund found inspiration in Lakoff's Women, Fire, and Dangerous Things [1987] [Asplund 1991: 10-12]. 


\section{Method} accessed via a link on the front page of The Pirate Bay website. This survey was a follow up to a similar survey conducted a year earlier. The study is sometimes referred to as the Research Bay study due to the fact that during its 72 hours of operation, it replaced the famous Pirate Bay ship logo with another that depicted a magnifying glass over the ship (Andersson, Schwarz \& Larsson [2013]; Larsson et al [2012]; Svensson et al. [2014]). This article uses the data retreived from the second survey. During the 72 hours the survey was conducted, it received over 96,000 responses from across the world. More specifically, it is the responses from the almost 20,000 French and US respondents that are analysed in this study. The survey included an open section where the respondents could freely answer the following question:

Please give us your own comments on the topic of file-sharing, especially how the situation in your home country looks and what you think will be the next big thing when it comes to the Internet and/or file-sharing. opportunity to categorise the respondents according to downloading frequency, uploading frequency, geography, age, and gender. A comparison is made between the answers from the US and the French respondents. Given this specific site's character of being one of the most well-knowned facilitators for file-sharing through the BitTorrent protocol, it is likely that the respondents accessing the survey from this environment represent a file-sharing community. This means that this specific sample of file-sharers can tells us about a wider file-sharing community. What further corroborates that both the French and the American respondents are of a similar category can be seen in the fact that both groups share similar demographics in the study, for example in terms of gender, with a strong majority of males (French: 93.4 per cent, American: 92.4 per cent), and youth, where almost 80 per cent of both the French and the US respondents are younger than 30 years old (almost half are between 18 and 24).

There were 18,483 US respondents to the survey, and if you exclude those that never fileshare, the number is 17,244 . If you select those that download the most frequently, namely every or almost every day, the number of respondents is 4,730 , which represents 26.8 per cent of the US respondents (see Table 3). The total amount of respondents from France is 1,444 , and if you exclude those that never file-share, the number is 1,271 . If you select those that download the most frequently, namely every or almost every day, the number of respondents is 478 , which represents 35.5 per cent of the French respondents (see Table 3). I have chosen to focus on those who download the most frequently under the assumption that they are also the most likely to have embraced the digital environment the strongest, may have the most elaborate justifications, and most likely do not share the norms that state that copyright infringement in online sharing is morally or socially wrong. In short, their actions reveal these respondents as being the furthest away from the requirements of copyright law.

Methodologically, the difference in size between the two samples poses a challenge. The American number of respondents being more than twelve times as high as the number of French respondents required on the one hand a normalisation of the data sets from the open-ended question so that they could be comparable, and on the other hand testing of 
to what extent the differences in findings between the two groups were statistically significant. Regarding the normalisation of data from the open-ended question, the answers from the most frequent French downloaders consisted of 179,948 characters. In order to be able to compare to the most frequent US downloaders, a random selection was made amongst this latter group to match the same amount of characters, see table 1 for further detail. A visual thesaurus called VocabGrabber was used to analyze the corpuses. Regarding the upload and download frequencies as well as the question of online anonymity, I have performed two-sample t-tests using a 95 per cent confidence interval to corroborate to what extent the differences are statistically significant. See table 2, 3 and 4 below for further detail.

\section{Findings and analysis}

The analysis in this section is combined with the presentation of data because they are so closely aligned. The subtitles represent the operationalised purpose presented above, that is, the four research questions.

\subsection{File-sharers' metaphors for copyright}

When it comes to the metaphors the online file-sharers use that might expose how they conceptualise copyright in a digital society, the top list of occurrences reveals little since words such as 'have', 'but', 'not' etc. are of less analytic relevance here. However, a top list of the concepts that are of clear relevance to copyright and file-sharing displays more interesting treats, see Table 1. Both groups responded in English, and therefore, the words have not been translated. 
Table 1: Occurrences of relevant concepts divided into French and US respondents

\begin{tabular}{|l|l|l|}
\hline Occurrences & French resp. & US resp. \\
\hline 1. & Share (371) & Share (390) \\
\hline 2. & Sharing (306) & File (341) \\
\hline 3. & File (271) & Sharing (334) \\
\hline 4. & Law (212) & Internet (239) \\
\hline 5. & Internet (203) & People (183) \\
\hline 6. & People (197) & Government (163) \\
\hline 7. & Download (153) & Medium (138) \\
\hline 8. & Good (116) & Law (100) \\
\hline 9. & Money (99) & Free (95) \\
\hline 10. & Free (96) & Industry (89) \\
\hline
\end{tabular}

The responses from the most frequent French downloaders consisted of 179,948 characters, while the number of responses from the most frequent American donwloaders was far larger. For this reason, a selection was made in the latter group's responses to a corpus of text consisting of the same amount of characters. This normalisation of the data was made in order to be able to compare the occurences of specific concepts in the responses from the two groups.

Here we see some slight discrepancies that are of clear interest. For example, the fact that 'industry' and 'government' receive such a high rank in the US context likely reflects the US debate overall in which the Hollywood industry and the American trade association representing the six big Hollywood studios, MPAA, are so clearly present (see Table 1). Although industrial involvement is not insignificant in the French context, the link between the government and the industry is central in the US context. Table 1 reveals that the respondents tend to use metaphors for 'sharing' rather than any references to 'property' when it comes to understanding copyright. This also means that they are more inclined to speak, and think, in terms of 'copyright' rather than 'intellectual property', which is relevant not the least to the rhetorical colonisation mentioned above.

\section{2. (Intellectual) Property}

When it comes to how the frequent downloaders understand property and intellectual property, one can begin by stating that the terms 'intellectual property' and 'property right' occur four times amongst the US respondents. They tend not to discuss this rightsbased side of copyright in that sense. In the answers from the French respondents, 'property' occurs eight times and 'intellectual property' six times. Most of the answers are highly critical and, in the French group, often refer to the HADOPI law in very critical terms. From this lack of conceptualisation of file-sharing as relating to property, we conclude that it completely opposes the US development mentioned above, where the 
media industry pushes for the "property" aspects of copyright - the P in IP (Herman [2008]; Jakobsson [2012]; Larsson [2012b]).

\subsection{Community and norms}

First of all, this is a survey of the file-sharing community, of which more than half (56.7 per cent) of the American respondents and almost 70 per cent of the French respondents download more than once a week, see Table 2. This means that this particular group is highly unlikely to share the norm that copyright should be upheld in a digital context, at least not in terms of copy protection, which is different from, say, attribution (cf. Svensson et al. [2014]; Svensson \& Larsson [2012]). As mentioned, to test that the observed differences between French and US respondents are statistically significant I performed two-sample t-tests. Using a 95 per cent confidence interval, results suggest that all differences regarding downloading behaviour are statistically significant at the 10 per cent level, see table 2. Similarly, with the exception of respondents answering, "I do not know", the differences between the two groups are significant for all response alternatives when asking about the use of VPN services, see table 4 . However, test statistics indicate that the noted difference in uploading behaviour between French and US respondents only is significant when it comes to high frequency users, i.e. those that upload material more than once a week or every day, see table 3.

Table 2: Download frequency by the US and France respondents

\begin{tabular}{|l|l|l|l|}
\hline Download frequency & $\begin{array}{l}\text { US (\% of this } \\
\text { column) }\end{array}$ & $\begin{array}{l}\text { France (\% of this } \\
\text { column) }\end{array}$ & $\begin{array}{l}\text { Statistically significant } \\
\text { difference }\end{array}$ \\
\hline Never & $1,239(7 \%)$ & $77(5.7 \%)$ & $*$ \\
\hline $\begin{array}{l}\text { More than once a } \\
\text { month }\end{array}$ & $6,387(36.2 \%)$ & $330(24.5 \%)$ & $*$ \\
\hline More than once a week & $5,274(29.9 \%)$ & $463(34.3 \%)$ & $*$ \\
\hline $\begin{array}{l}\text { Every day or almost } \\
\text { every day }\end{array}$ & $4,730(26.8 \%)$ & $478(35.5 \%)$ & $*$ \\
\hline Total & 17,630 & 1348 & \\
\hline
\end{tabular}

Table 3: Upload frequency by the US and France respondents

\begin{tabular}{|l|l|l|l|}
\hline Upload frequency & $\begin{array}{l}\text { US (\% of this } \\
\text { column) }\end{array}$ & $\begin{array}{l}\text { France (\% of this } \\
\text { column) }\end{array}$ & $\begin{array}{l}\text { Statistically significant } \\
\text { difference }\end{array}$ \\
\hline Never & $11,433(65.6 \%)$ & $853(64.6 \%)$ & \\
\hline $\begin{array}{l}\text { More than once a } \\
\text { month }\end{array}$ & $4,277(24.5 \%)$ & $303(22.9 \%)$ & \\
\hline
\end{tabular}




\begin{tabular}{|l|l|l|l|}
\hline More than once a week & $1,020(5.9 \%)$ & $94(7.1 \%)$ & $*$ \\
\hline $\begin{array}{l}\text { Every day or almost } \\
\text { every day }\end{array}$ & $693(4 \%)$ & $71(5.4 \%)$ & $*$ \\
\hline Total & 17,423 & 1321 & \\
\hline
\end{tabular}

How frequently VPN or other, similar tools, i.e. technological tools that leave fewer traces in an online environment, are used (cf. Larsson \& Svensson [2010]; Larsson et al. [2012]), may tell us something of the attitude towards legal enforcement in this context. This relates to "computational traceability" in RQ3.

Table 4: Use of VPN or similar service to protect anonymity

\begin{tabular}{|l|l|l|l|}
\hline & $\begin{array}{l}\text { US (\% of this } \\
\text { column) }\end{array}$ & $\begin{array}{l}\text { France (\% of this } \\
\text { column) }\end{array}$ & $\begin{array}{l}\text { Statistically significant } \\
\text { difference }\end{array}$ \\
\hline Yes, free service & $14.4 \%(2,463)$ & $10.2 \%(132)$ & $*$ \\
\hline Yes, paid service & $5.9 \%(1,009)$ & $8.8 \%(114)$ & $*$ \\
\hline $\begin{array}{l}\text { No, but I'd like to be more } \\
\text { anonymous online }\end{array}$ & $59 \%(10,109)$ & $56.4 \%(730)$ & $*$ \\
\hline $\begin{array}{l}\text { No, I do not care about } \\
\text { anonymity }\end{array}$ & $12.4 \%(2,132)$ & $16.9 \%(219)$ & $*$ \\
\hline I do not know & $8.3 \%(1,419)$ & $7.7 \%(99)$ & \\
\hline Total & 17,132 & 1294 & \\
\hline
\end{tabular}

We can see that both groups are similarly inclined to be less traceable online, although the French file-sharers to a higher degree use pay-services for it. Interestingly enough, a majority in both groups would prefer to be more anonymous online, see Table 4, which could be interpreted as a clear indication that they do not share the norms that the law prescribes in this field.

\subsection{US v. France}

Given the data in this study, it is hard to establish a more detailed connection between national, historical attitudes towards copyright and the file-sharing communities in the two nations. However, it is still interesting to note that there are differences between the French and the American downloaders which may be worthy of contemplation in, for example, further studies. In this regard, there are some concepts that stand out in comparison. In the answers from the French respondents, there were 78 occurrences of the word 'artist', 35 occurrences of 'industry', and 62 of 'government.' In the US respondents' answers, there were only 32 occurrences of the word 'artist', 89 of the word 
'industry', and 163 of 'government.' This can be seen in quotes from the French filesharers such as:

"I've never spent so much money in music, movies, and software since I've started doing voluntary donations to Creative Commons music/movies/series, to free and opensource software developpers, and other artists I like"

"I guess the biggest issue is supporting the artists/persons who released the file we share"

"T.P.B. is one great place where I can Download and listen freely to music and movies, and then buy them if they please me, because true artists deserve MY money."

These are interesting and relevant concepts, and they reveal something of a difference between the two groups. This can be seen in quotes such as: "The current trend is towards increased surveillance by government/industry" (American file-sharer). For others, there is a spirit of resistance and counter activity in file-sharing or, at least, in their justifications (see also Andersson Schwarz \& Larsson [2013]). One of the earliest artists to oppose file-sharing was the drummer in the rock band Metallica, Lars Ulrich (later nicknamed Lar\$), who participated in the law suits against Napster in April 2000. This has become a symbol that still lives on in the file-sharing community:

"Fuckers. The industry needs to embrace technology. If I had more legal options, I wouldn't steal. Sometimes a bit of disobedience is needed, I download the metallica discography at least twice per week, then immediately delete it (metallica isn't even that good), just to piss off lars" (US file-sharer).

For the US file-sharing community, it is far more common to speak of the industry and the government when thinking about the future of copyright. When conceptualising filesharing and copyright, the findings in the US respondents indicate that they tend to think more in terms of how they relate to government and the entanglement of the industry in a societal context. This can be compared to the findings in the French file-sharing community which focuses - in line with the historical attitudes outlined above - more on the artists. It is also more common in the American file-sharing group to speak of the 'market' ( 72 occurrences) and the idea that the industry should 'adapt' ( 69 occurrences), as compared to 42 occurrences for 'market' and 43 occurrences for 'adapt' amongst the French file-sharers.

\section{Conclusion}

The purpose of this study has been to better understand how file-sharers conceptualise copyright and unauthorised file-sharing in a digital, online context. In order to do that, this study uses the open-ended answers from a large-scale online survey of the filesharing community and divides the answers into one group of 17,244 US respondents and one group of 1,271 French respondents. The results indicate that there is a difference between how the French and the American file-sharers understand or conceptualise the future of file-sharing and its relationship to copyright. For example, the American filesharers are more inclined to speak of the 'market', 'government' and the 'industry', and the French file-sharers are more inclined to speak of the 'artists' and their remuneration. This can, at a surface level, be seen in the terminological difference between 'intellectual property', that is the common concept in American copyright discourse, as opposed to the droit d'auteur - the author's right - in the French and continental copyright tradition. In other words, the findings can be interpreted to indicate that the US 
respondents are more inclined to conceptualise the issue in the context of a social dilemma that follows from a 'utilitarian' tradition, while the French norm and culture is in line with the notion that the creators should receive the benefits; this, then, constitutes the challenge the French respondents relate to, in a droit d'auteur tradition.

A majority of the file-sharers in both groups prefer to be more anonymous online which, in light of the fact that they know that file-sharing often is illegal, is a sign that the social norm that they are likely to act in accordance with is not in line with the legal norms of copyright. Further, this is likely connected to the fact that the file-sharers do not conceptualise copyright in terms of 'property' or similar notions, but rather in terms of 'sharing.'

\section{BIBLIOGRAPHY}

ANDERSSON SCHWARZ Jonas \& LARSSON Stefan, "On the Justifications of Piracy: Differences in conceptualization and argumentation between active uploaders and other file-sharers", in ARVANITAKIS James \& FREDRIKSSON Martin (eds.), Piracy: Leakages from Modernity, Los Angeles, CA: Litwin Books, 2013.

AREWA Olufunmilayo B., "From J.C. Bach to Hip Hop: Musical Borrowing, Copyright and Cultural Context", North Carolina Law Review 84.2, 2006: 547-645.

ASPLUND Johan, En essä om Gemeinschaft och Gesellschaft, Göteborg: Bokförlaget Korpen, 1991.

BANAKAR Reza, "Who Needs the Classics? - On the Relevance of Classical Legal Sociology for the Study of Current Social and Legal Problems", in HAMMERSLEV Ole \& MADSEN Mikael Rask (eds.), Retssociologi, Copenhagen: Hans Reitzels Forlag, 2012.

BERGER Linda L., "How embedded knowledge structures affect judicial decision making: A rhetorical analysis of metaphor, narrative, and imagination in child custody disputes", $18 \mathrm{~S}$. Cal. Interdisc. L.J. 259, 2009.

BERGER Linda L., "Of Metaphor, Metonymy, and Corporate Money: Rhetorical Choices in Supreme Court Decisions on Campaign Finance Regulation”, Mercer Law Review 58:949, 2007.

BERGER Linda L, "What is the sound of a corporation speaking? How the cognitive theory of metaphor can help lawyers shape the law", 2 J. Ass'n Legal Writing Directors 169, 2004.

BLAVIN Jonathan H. \& COHEN I. Glenn, "Gore, Gibson, and Goldsmith: The Evolution of Internet Metaphors In Law and Commentary”, Harvard Journal of Law and Technology, Vol. 16, No. 1, 2002.

CASS Kimberly \& LAUER Thomas W., "Media transitions. The cases of digital imagery and e-mail", Information Technology \& People, vol. 17, no. 3, 2004: 252-267.

CASTELLS Manuel, The Rise of the Network Society. The Information Age, Economy, Society and Culture, Vol. 1. Oxford: Blackwell Publishing, 1996.

FELDMAN Yuval \& NADLER Janice, “The law and norms of file sharing”, The San Diego Law Review 43 (3), 2006: 577-618. 
FREDRIKSSON Martin, Skapandets rätt. Ett kulturvetenskapligt perspektiv på den svenska upphovsrättens historia. Avhandling i filosofi, Linköpings universitet. Göteborg: Daidalos, 2009.

HEMMUNGS WIRTÉN Eva, Cosmopolitan Copyright: Law and Language in the Translation Zone, Uppsala: Meddelanden från Institutionen för ABM vid Uppsala universitet $\mathrm{Nr}$ 4, 2011.

HERMAN Bill D, "Breaking and entering my own computer: The contest of copyright metaphors", Communication Law and Policy 13(2), 2008: 231-274.

HUNTER Dan, "Cyberspace as Place and the tradegy of the digital anticommons", California Law Review, 2003.

HYDÉN Håkan and SVENSSON Måns, "The Concept of Norms in Sociology of Law", in WAHLGREN Peter (ed.) Scandinavian Studies in Law Stockholm: Law and Society, 2008.

JAKOBSSON Peter Öppenhetsindustrin, Örebro Studies in Media and Communication 13, Södertörn Doctoral Dissertations 65, 2012.

JOHNSON Mark L., The body of the mind: The bodily basis of meaning, imagination, and reason, Chicago, IL, US: University of Chicago Press, 1987.

JOHNSON Mark L., "Law incarnate”, 67 Brooklyn Law Review, 2002: 950.

JOHNSON Mark L., “Mind, Metaphor, Law”. 58 Mercer Law Review, 2007: 845-868.

Joo Thomas W., "Contract, Property and the Role of Metaphor in Corporations Law", UC Davis Daniel J. Dykstra Memorial Corporate Governance Symposium, 2001.

KARAGANIS Joe, GRASSMUCK Volker \& RENKEMA Lennart, Copy culture in the US and Germany, New York: Columbia University, The American Assembly, 2012.

LAKOFF George, Women, fire and dangerous things: What categories reveal about mind, Chicago, IL: University of Chicago Press, 1987.

LAKOFF George \& TURNER Mark, More than cool reason: A field guide to poetic metaphor, Chicago: University of Chicago Press, 1989.

LAKOFF George \& JoHnson Mark L., Metaphors we live by, Chicago: University of Chicago Press, 1980.

LAKOFF George \& JOHNSON Mark L., Philosophy in the flesh: the embodied mind and its challenge to Western thought, New York: Basic Books, 1999.

LARSSON Stefan, "Conceptions, Categories, and Embodiment - why metaphors are of fundamental importance for understanding norms", in BAIER Mathias (ed.), Social and Legal Norms. Towards a socio-legal understanding of normativity, Ashgate Publishing, 2013a.

LARSSON Stefan, "Conceptions in the code: What 'the copyright wars' tells about creativity, social change and normative conflicts in the digital society", Societal Studies, 4(3), 2012a: 1009-1030.

LARSSON Stefan, “Copy Me Happy - The Metaphoric Expansion of Copyright in a Digital Society”, International journal for the Semiotics of Law, vol 26, online first, 2012b.

LARSSON Stefan, "Metaforerna och Rätten", Retfæerd Nordic Journal of Law and Justice 2 (137), 2012c: 69-93.

LARSSON Stefan, Metaphors and Norms. Understanding Copyright Law in a Digital Society, PhD Thesis, Lund Studies in Sociology of Law, Lund University, 2011.

LARSSON Stefan, "Metaphors, Law and Digital Phenomena: The Swedish Pirate Bay Court Case", International Journal of Law and Information Technology, Advance Access, 2013b. 
LARSSON Stefan \& HYDÉN Hydén, "Law, deviation and paradigmatic change: Copyright and its metaphors", in VARGAS MARTIN Miguel, GARCIA-RUIZ Miguel A. \& EDWARDS Arthur (eds.) Technology for Facilitating Humanity and Combating Social Deviations: Interdisciplinary Perspectives, Hershey, PA, USA: IGI Global, 2010: 188-208.

LARSSON Stefan, SVENSSON Måns, DE KAMINSKI Marcin, RÖNKKÖ Kari, ALKAN OLSSON Johanna, “Law, Norms, Piracy and Online Anonymity - Practices of de-identification in the global file sharing community", Journal of Research in Interactive Marketing 6(4), 2012: 260-280.

LESSIG Lawrence, Free culture: how big media uses technology and the law to lock down culture and control creativity, New York: Penguin books, 2004.

LESSIG Lawrence, Remix: Making art and commerce thrive in the hybrid economy, New York: Penguin Press, 2008.

LOUGHLAN Patricia, "Pirates, parasites, reapers, sowers, fruits, foxes...The metaphors of intellectual property", Sydney Law Review 28(2), 2006: 211-226.

PATRY William, Moral panics and the copyright wars, Oxford University Press, 2009.

RITCHIE David T, "Who is on the Outside Looking In and What Do They See?: Metaphors of Exclusion in Legal Education", 58 Mercer Law Review, 2007.

ROSE Mark, Authors and Owners. The invention of copyright, Harvard University Press, 1993.

SAMUELSON Pamela, "Implications of the Agreement on Trade Related Aspects of Intellectual Property Rights for Cultural Dimension of National Copyright Laws", Journal of Cultural Economics, Vol. 23(1), 1999: s. 95-107.

SVENSSON Måns, "Norms in Law and Society", in BAIER Mathias (ed.), Social and Legal Norms. Towards a socio-legal understanding of normativity, Ashgate Publishing, 2013.

SVENSSON Måns \& LARSSON Stefan, "Intellectual Property Law Compliance in Europe: Illegal File sharing and the Role of Social Norms”, New Media \& Society, 14(7), 2012: 1147-1163.

SVENSSON Måns, LARSSON Stefan \& DE KAMINSKI Marcin," The Research Bay - studying the global file sharing community", in GALLAGHER William \& HALBERT Debora (eds.) Intellectual Property in Context: Law and Society Perspectives on IP, Cambridge: Cambridge University Press, 2014.

TRIM Richard, Metaphor Networks. The comparative evolution of figurative language, Palgrave Macmillan, 2007.

TSAI Robert L, “Fire, Metaphor, and Constitutional Myth-Making”, Georgetown Law Journal 93.1, 2004: 181-239.

VON LEWINSKI Silke, International Copyright Law and Policy, Oxford: Oxford University Press, 2008. WINTER Steven L., A clearing in the forest: Law, Life, and Mind, Chicago and London: University of Chicago Press, 2001.

WINTER Steven L., "Frame semantics and the 'internal point of view"', in FREEMAN Michael \& SMITH Fiona (eds.), Current Legal Issues Colloquium: Law and Language, Oxford University Press, 2011.

WINTER Steven L., “Re-embodying Law”, 58 Mercer Law Review, 2007.

WINTER Steven L., "What is the 'color' of law?", in GIBBS JR. Raymond W. (ed.), The Cambridge Handbook of Metaphor and Thought, Cambridge University Press, 2008.

WOODMANSEE Martha, The author, art and the market. Rereading the history of aesthetics, New York: Columbia University Press, 1994. 


\section{ABSTRACTS}

What type of metaphors do file-sharers employ to conceptualise copyright in a digital society? How do they understand property and intellectual property in this context? How do they conceive the file-sharing community and how does this 'online piracy' connect or not connect to law, social norms, copyright enforcement, and computational traceability? Given the historical variations in the inherent emphasis on ownership and attribution in copyright law within an American vis-à-vis a French continental context, are there, for example, noticeable differences between the American and the French respondents? By drawing heavily from conceptual metaphor theory, this article analyses findings from a large-scale survey (20,000 respondents) on online file-sharing. The results indicate that copyright is not seen as 'property' by the respondents at all, that a majority of the US and French file-sharers would prefer to be more anonymous online in order to avoid legal enforcement, and that almost one out of five already uses such tools. The results indicate that there is a difference in how the American and the French file-sharers understand or conceptualise the future of file-sharing and its relationship to copyright and that the French file-sharers focus more on the actual artists, while the American file-sharers focus more on the role of the industry and the government.

\section{INDEX}

Keywords: copyright, conceptual metaphor, file-sharing, Pirate Bay (the), intellectual property

\section{AUTHOR \\ STEFAN LARSSON}

Department for Sociology of Law, Lund University, Sweden

stefan.larsson@soclaw.lu.se 